Fruitless Trees 



\section{Fruitless Trees}

PORTUGUESE CONSERVATION AND

BRAZIL'S COLONIAL TIMBER

SHAWN WILLIAM MILLER

Stanford University Press

Stanford, California 
Stanford University Press

Stanford, California

(C) 2000 by the Board of Trustees of the Leland Stanford Junior University

Printed in the United States of America

CIP data appear at the end of the book 
To my mother

Sheila May Miller, née Mohr 
